\title{
Recreational Boat Carrying Capacity of Vembanad Lake Ecosystem, Kerala, South India
}

\author{
B. Rajan, V. M. Varghese and A. P. Pradeepkumar \\ School of Environmental Sciences, Mahatma Gandhi University, Kottayam, India
}

(received in April, 2011, accepted in June, 2011)

\begin{abstract}
Recreational carrying capacity refers to the number of boats that can be operated on a lake without compromising safe recreational use, aesthetic enjoyment, and/or environmental quality. Lakes are a finite resource with seemingly unlimited demand. This fact, coupled with a tremendous increase in the number, size, and speed of today's watercraft, has brought the issue of lake access and overcrowding to the forefront in many communities. As lake use increases, environmental quality, user enjoyment, and safety may decrease. To keep our lakes available for multiple uses, it is helpful to learn about their recreational carrying capacity. The present study is a first attempt to evaluate the boat carrying capacity as well as the recreational carrying capacity of Vembanad lake. quality.

Key words: Recreational carrying capacity, Vembanad lake; boat carrying capacity, environmental
\end{abstract}

\section{Introduction}

When the globalization process is carving out a niche in the entire spectrum of human systems especially on his/her economic and social existence, his/her search for mental peace and tranquillity ends in movement, travel and pleasure seeking. This unprecedented socio - cultural evolution is transforming into a tourism revolution in the entire world and as a result the tourism sector is becoming the most important and critical one in sharing the economic development and employment generation across the world. The tourism sector occupies a catalytic and pivotal position in the world economy, including India and particularly Kerala.

The World Travel and Tourism Council (WTTC) have identified India as one of the world's foremost tourist growth centres in the coming decade. After Turkey, India is expected to achieve the fastest rate of growth of the total amount of economic activity likely to be generated by travel and tourism, at $9.7 \%$ over the next 10 years. Also, the largest employment creation after China is expected to take place in India over the same period. The growth in visitor imports or spending by international tourists is likely to be the fastest in India at $14.3 \%$ per annum over the next decade.

Tourism has emerged as a leading sector of the Kerala economy, with its impact increasing in terms of economic growth and employment generated (GOK 2002 a \& b). The state government views tourism as one of the few alternatives available to develop the economy, especially in the context of limited prospects of the manufacturing sector, problems in the agricultural and traditional sectors, and the uncertainties facing the expatriate employment in the Persian Gulf (Pushpangadan 2003). Kerala is now considered as a tourism model for other states in India to emulate its growth. Tourism industry in Kerala witnessed a considerable growth during the nineties and beyond and it is expected to grow further in the future. Kerala is one of the earliest Indian states to announce industry status for tourism in 1986 and announce various incentives and subsidies to attract investment (Rao and Suresh 2001).

Kerala's share of international tourists coming to India has increased from $5.54 \%$ in 1994 to $8.85 \%$ in 2005 making it a leading state for tourism in the 
country. Earnings from tourism are also projected to grow at a record level of more than $23.5 \%$ which is very high, higher than the earnings growth projected for India and world average which is $14.3 \%$ and 6.5 $\%$. During the same period, tourism receipts from international tourists also grew considerably, from 116 crore( Indian English ten million) in 1994 to 1988.40 crore in 2006 (GOK 2006). International tourist arrivals to Kerala had reached almost half million in 2006, and it was expected to cross 5 lakhs (Indian English a hundred thousand) by 2007. For the domestic tourism, the arrivals had crossed 60 lakhs in 2006. This almost meets the prediction of the WTTC that with an average annual arrival growth rate of $18 \%$ for domestic tourists and $12 \%$ for international tourists Kerala is becoming one of the fastest growing destinations in the world (WTTC 2002). The growth of domestic and international tourism in Kerala and its relative position in the Indian tourism in the recent past is depicted in Tables 1 and 2 .

Table 1. Summary of optimum boating densities

\begin{tabular}{|c|c|c|}
\hline Source & $\begin{array}{l}\text { Suggested } \\
\text { Density }\end{array}$ & " Boating Uses \\
\hline \multirow[t]{3}{*}{$\begin{array}{l}\text { Ashton } \\
\text { (1971) }\end{array}$} & $\begin{array}{l}5 \text { to } 9 \\
\text { acres/boat }\end{array}$ & $\begin{array}{l}\text { All uses combined in } \\
\text { Cass Lake }\end{array}$ \\
\hline & $\begin{array}{l}4 \text { to } 9 \\
\text { acres/boat }\end{array}$ & $\begin{array}{l}\text { All uses combined in } \\
\text { Orchard Lake }\end{array}$ \\
\hline & $\begin{array}{l}6 \text { to } 11 \\
\text { acres/boat }\end{array}$ & $\begin{array}{l}\text { All uses combined in } \\
\text { Union Lake }\end{array}$ \\
\hline \multirow[t]{3}{*}{$\begin{array}{l}\text { Kulser } \\
(1972)\end{array}$} & $\begin{array}{l}40 \\
\text { acres/boat }\end{array}$ & $\begin{array}{l}\text { Waterskiing }- \text { All } \\
\text { uses combined }\end{array}$ \\
\hline & $\begin{array}{l}20 \\
\text { acres/boat }\end{array}$ & Waterskiing \\
\hline & $\begin{array}{l}15 \\
\text { acres/boat }\end{array}$ & $\begin{array}{ll}\text { Co } & \text { ordinate } \\
\text { Waterskiing }\end{array}$ \\
\hline \multirow[t]{4}{*}{$\begin{array}{ll}\text { Jaakson et } \\
\text { al. (1989) }\end{array}$} & $\begin{array}{l}20 \\
\text { acres/boat }\end{array}$ & $\begin{array}{l}\text { Waterskiing and } \\
\text { motor boat cruising }\end{array}$ \\
\hline & $\begin{array}{l}10 \\
\text { acres/boat }\end{array}$ & Fishing \\
\hline & $\begin{array}{l}8 \\
\text { acres/boat }\end{array}$ & $\begin{array}{l}\text { Canoing, kayaking, } \\
\text { sailing }\end{array}$ \\
\hline & $\begin{array}{l}10 \\
\text { acres/boat }\end{array}$ & All uses combined \\
\hline $\begin{array}{l}\text { Wagner } \\
\text { (1991) }\end{array}$ & $\begin{array}{l}25 \\
\text { acres/boat }\end{array}$ & $\begin{array}{l}\text { All recreational } \\
\text { activities }\end{array}$ \\
\hline $\begin{array}{l}\text { Warbach et } \\
\text { al.(1994) }\end{array}$ & $\begin{array}{l}30 \\
\text { acres/boat }\end{array}$ & $\begin{array}{l}\text { All motorized }(>5 \\
\text { HP) uses }\end{array}$ \\
\hline
\end{tabular}

Tourism is also counted as an important alternative to address unemployment which is a major problem facing the state (Kokkranikal and Morrison 2002). Further reasons making tourism industry attractive for the state includes its strong linkages with other sectors in the state, and its potential for generating benefits more widespread throughout the state for a given level of the capital investment compared to other sectors. A study done shows a strong multiplier effect for the tourism industry in the state for both output multiplier and employment multiplier (TCS 2000). With regard to employment generation in the state, the travel and tourism industry is expected to create 7.5 lakhs jobs in the next 10 years and the broader impact of it on the economy can create 1.4 million jobs during this period (WTTC 2002).

Table 2. Physical Capacity Assessment

\begin{tabular}{|l|l|l||}
\hline $\begin{array}{l}\text { Density } \\
\text { classification }\end{array}$ & $\begin{array}{l}\text { Density } \\
\text { range } \\
\text { (acres/boat) }\end{array}$ & $\begin{array}{l}\text { Physical } \\
\text { Capacity } \\
\text { Assessment }\end{array}$ \\
\hline Very high density & $\leq 10.0$ & $\begin{array}{l}\text { Exceeding } \\
\text { capacity }\end{array}$ \\
\hline High density & $10.1-20.0$ & $\begin{array}{l}\text { Approaching } \\
\text { capacity }\end{array}$ \\
\hline Moderate density & $20.1-50.0$ & Below capacity \\
\hline Low density & $>50$ & Below capacity \\
\hline
\end{tabular}

Adopted from Reservoir Boating, Final $R-7$, Oroville Facilities Relicensing FERC Project No.2100, by EDAW 2004a, p.p.5-73

Tourism industry is a recently entered phenomenon to the area which offers employment opportunities for local communities and an important source of revenue to the state. Nearly $2 \%$ of the local adult population of Kumarakom village on the eastern banks of Vembanad lake are employed in the tourism sector. Large scale land filling is taking place in Kumarakom for resort construction and other tourism amenities. Hundreds of house boats are directly discharging from house boats and other motor boats into the lake. The present study is a first attempt to evaluate the boat carrying capacity as well as the recreational carrying capacity with respect to Vembanad lake.

Houseboats (Rice boats) are country boats that were used in the early days for the transport of goods from isolated interior villages to towns. But, in a few years time, the situation has changed dramatically because of momentous regional development schemes. Roads, bridges and motorized ferry services came to the area and people began taking advantage of modern amenities. As a result, rice boats became anachronistic and ceased to occupy a spot in the economic geography of the region. Now these are back again as a major tourist attraction. A house boat is about 67 to 95 feet in length and has a width of around 13 feet to in the middle. House boats have fully furnished single double triple and five bedrooms with sundeck, private balcony with comfortable chairs, kitchen and toilet.

\subsection{Concept of Recreational Carrying Capacity}

It should be recognized at the onset that the concept of recreational carrying capacity is as much perception as science (Mahoney and Stynes 1995). Although research shows that a higher density of boats increases the potential for negative impacts, there have been no conclusive studies that answer the question: How many boats are too many? (Wagne 1991). Each lake is different, and various lake users 
will have different perspectives on what constitutes congestion. Thus, there is no single boating density standard that will satisfy all lake users in all situations.

In light of these considerations, a recreational carrying capacity study should not be used as a sole determining factor limiting lake use or access. Rather, a recreational carrying capacity analysis should be used as a tool to evaluate the range of options that are available to help minimize multiuse conflicts, environmental concerns, and other problems associated with lake overcrowding. A recreational carrying capacity study can establish a framework for decision making and provide a basis for regulatory action.

At its core, the concept of recreational carrying capacity appears simplistic. The area of the lake that is suitable for boating is divided by the desired boating density. For example, if a lake is 100 acres, and the desired boat density is ten acres per boat, then the recreational carrying capacity would be a maximum of ten boats:

100 acres $\div 10$ acres per boat $=10$ boats

However, in estimating recreational carrying capacity, a number of factors need to be considered. Key factors that should be evaluated include lake physical characteristics, use characteristics (i.e., the number of lakeside homes, moored boats, the number and type of access sites, and current boating activity), environmental impacts, useable lake area, boating density, and lake use rate. These factors are discussed in more detail further in the report.

\section{Study Area}

The Vembanad wetland ecosystem complex is the largest tropical wetland system of the south west coast of India including back waters, marshes, lagoons, mangrove forests, reclaimed land and a network of natural and manmade canal systems. Because of its global importance and biodiversity values it is included under the Ramsar site in November 2002. Four canals - Thottappally, Andhakaranazhi, Kochi and Azhikode connect the lake to the sea. The lake is fed by six major rivers from Western Ghats; the Achenkovil, Pampa, Meenachil, Manimala, Muvattupuzha and Periyar. Total length of the lake is $96 \mathrm{~km}$., the area of the lake south to Thannermukkam bund is 13,224 hect. and the area of the lake north of Thannermukkam bund is 23,500 hect. The total surface area is 36,500 hect. 1.6 million people live on the banks of the lake. Agriculture, fishing, tourism, inland navigation, coir retting, sand mining and lime shell collection are major livelihoods of people on the banks of wetland. The lake system supports $1,100 \mathrm{~km}^{2}$ of paddy fields.

The Vembanad - Kol - Wetland - System, one of the three Ramsar sites in Kerala (November 2002), is the largest estuarine system of the western coastal wetland systems $\left(09^{\circ} 00^{\prime}-10^{\circ} 40^{\prime} \mathrm{N}\right.$ Latitude and $76^{\circ}$ $00^{\prime}-77^{0} 30^{\prime}$ E Longitude) west of Kottayam town in
Kerala, South India. Its biodiversity consists of phytoplanktons- 67 sps., herbs, shrubs - 142, trees 68 and the fauna consists of zooplanktons -32 , fishes 102, insects 26 and birds 189. Prof. K. K. Neelakandan, renowned ornithologist reported thousands of Night Herons, Darters and Cormorants breeding in the mangrove forests of Kumarakom. Vembanad Lake has been identified as one of India's Important Bird Areas (Islam \&Rahmani 2004). The heronry covers 112 acres (45.3 ha), and is $14 \mathrm{~km}$ west of the town of Kottayam. During the winter months, Vembanad supports the third largest population of more than 20,000 waterfowls in India. Floristic diversity of the area includes 14 mangroves and more than 30 mangrove associates, present in the area. Mangrove forests are also the feeding and breeding grounds for numerous species of fishes. The wetlands support diverse fauna, including a large variety of fishes, prawns and clams, reptiles and birds and provide a habitat for both anadromous and catadromous fish species. The fish fauna identified from the whole area comes around to 102 species, mainly of mullets. Molluscs include the black clam (Velorita cyprinoids; V. cornucopia), Mertrix meretrix, $M$. costa and Ostria calculata. The mussels, Perna viridis and $P$. indica and the brackish water oyster, Crassostrea madrasensis, occur abundantly in the backwaters and river mouths. Vembanad-Kol, acts as a nursery for important shrimps like Penaeus indicus, P. monodon, Metapenaeus dobsoni, M.monoceros, M. affinis, Macrobrachium rosenbergii. Marine prawns, belonging to the family Penaeidae, are exploited both in the marine and estuarine waters. They spawn in the sea and their larvae migrate to the estuary to feed on the nutrientrich environment. Among other Penaeids are Penaeus indicus, Metapenaeus monodon and M. dobsoni. The crustaceans include the edible crab Scylla serrata also.

\section{Materials and Methods}

This document will examine a variety of literature on recreational carrying capacity. Emphasis is placed on boating density methodology and other factors pertinent to the lake carrying capacity estimation. The boating carrying capacity studies that were reviewed contained the following categories of analysis: use characteristics, usable lake area, boating density, lake use rate, and boater's perceptions of crowding.

The recreational boating capacity concept implies that specific areas have certain use capacities that are sustainable, and these capacities can be identified and managed for a specific number of watercraft for the entire body of water. Such calculations can only provide a crude estimate of capacity. Therefore, the concept of recreational boating capacity on rivers, lakes, and reservoirs is complex. To obtain an accurate picture, estimation of boating capacity must include information about 
current boating conditions, and identify a desired future condition that is agreed upon by managers and visitors alike. Once this is accomplished, appropriate strategies can be developed to address the objectives for short and long-term planning.

As the number of watercraft and the level of congestion increases on a given lake, so does the probability of conflict due to competition for the limited space. "The ability of a lake to accommodate a given number of users and mixed recreational uses depends on the compatibility of those uses" (Jones 1996). "While each water body may have special suitability for particular uses, the water body can accommodate only a limited number of such uses. Beyond this point, the overload of a single use, as well as interaction between several uses, causes conflict and perhaps damage to the water resource" (Kusler 1972). Increasing shore land development and lake-use pressures continue to threaten the quality of these public water bodies. In other words, the carrying capacity attempts to answer the question: how much is too much?

\subsection{Use Characteristics}

Use characteristics are those data which indicate how the lake is being used, and by whom. Carrying capacity studies use various techniques to estimate the total number of boats, the number and types of boats in use at peak and non-peak times, and the distribution of use between shoreline residents and visitors. Studies reviewed in the present document have utilized the following methods to estimate the use:

- On-the-water surveying;

- On-the-ground surveying, contact surveys;

- Parking lot vehicle counts.

\subsection{Usable Lake Surface Area}

The usable surface area is the area that can be used for boating. The most common way to calculate the usable lake surface area is to subtract a shoreline buffer zone of predetermined width from the total acreage of the lake. These buffer zone widths typically range from 100 to 200 feet. This area should exclude the area within the shore line, which is designated as the idle zone, sensitive habitat, swimming area and shallows less than 5 feet depth; which should be subtracted from the total surface area of the lake. The shore line buffer zone width typically varies from $30 \mathrm{~m}-40 \mathrm{~m}$. Jackson et al. (1990) have also recommended the buffer zone around emergent aquatic vegetation $-30 \mathrm{~m}$ and marinas and public swimming beaches $-1200 \mathrm{~m}$ (400 feet).

In several studies, the issue of depth fluctuation has also been addressed with regard to the surface area determination, since a lake with a lower depth will have a smaller total surface area. For the most conservative usable surface area calculation, the lowest lake depth should be used in conjunction with a shoreline buffer zone.

\subsection{Boating Density}

Boating density, measured in surface acres per watercraft, could be viewed as the most systematic component of the carrying capacity estimation process. Even so, optimum densities vary depending on users' preferred setting types and site-specific attributes. Additionally, some studies provide aggregate densities, applicable to the entire lake, while the others specify a density for each type of watercraft. This literature review includes a number of boating density standards. These acreage specifications range from 1.3 acres per watercraft for fishing from a boat, or canoeing/kayaking (Warren \& Rea 1989), to up to 3,200 acres per boat for a primitive recreational boating setting (Aukerman et al. 2004).

Boating density is a recommended spatial requirement, measured in acres per boat, for various types of watercraft. PAE provides a useful Table summarizing five studies on optimum boating densities. Most densities in this Table are aggregate, giving only a suggested density for all boating uses combined. The Table is reproduced below.

\subsection{Lake Use Rate}

Lake use rate is a measure of the estimated proportion of moored boats on the lake at any given time, plus the estimated percent capacity of public access sites. For boats moored at existing shoreline developments, research studies have estimated a peak use rate to range from $3.6 \%$ (ERM 2004) to $25 \%$ (Jaakson et al. 1990). If historical data on the lake use rate exist, those figures should be used instead of generic peak use rate recommendations. Percent capacity of the public access sites is only mentioned in one of the reviewed studies, and the recommended percentage for the lake use rate is $50 \%$, unless existing data or park staffs indicates otherwise (ERM 2004).

PAE states that "most environmental problems associated with boating activity occur in shallow waters" (p. 13). Thus, in addition to considering a shallowness ratio for the lake as a whole, PAE recommends a minimum 100-foot shoreline safety/environmental protection zone. Usable lake area is then calculated as the difference between total lake area and the shoreline safety/environmental protection zone. The Michigan state law is in place to enforce no-wake zones within 100 feet of the shoreline and in water less than three feet deep. PAE also raises an important point regarding water level fluctuations. When the water level drops, the usable lake area is reduced. Carrying capacity would thus be lower during the periods of the low lake level. The study does not provide any methodological 
suggestions for accounting for this fluctuation when estimating the usable lake area (Table 1).

\subsection{Lake Physical Characteristics}

Lake size, shape, and depth strongly influence recreational carrying capacity. They describe a sizeindependent measure of the lake shape, known as a shoreline development factor (SDF), which is defined as "a measure of the degree of irregularity in the shape of the shoreline" (PAE p. 3). SDF compares the actual length of the shoreline around a lake to the minimum shoreline length of a lake with the same area (i.e., if the lake were a perfect circle).

$S D F=$

Length of shoreline around the lake

Circumference of a circle with the area equal to that of the lake

A higher ratio indicates a more irregular shoreline. Irregular shorelines, with their coves and inlets, "may serve to isolate impacts...[but] also imply greater safety risks as well as ecological consequences" (Wagner 1991, as cited in PAE p. 3).

\subsection{Environmental Impacts}

Some of the more common impacts of boating activity are "fuel emissions from boat motors, suspension of bottom sediments, decreased water transparency, shoreline erosion, destruction of fish spawning areas, and loss of valuable fish and wildlife habitat" (PAE p. 10). The portions of the lake less than 5 feet deep are most susceptible to environmental impacts. As such, PAE has introduced a second ratio, called the shallowness ratio which is calculated as follows:

$\mathrm{SR}=\frac{\text { Area of the lake less than } 5 \mathrm{ft} . \text { deep }}{\text { Total area of the lake }}$

\subsection{Shallowness Ratio (SR)}

The shallowness ratio represents the proportion of the lake bottom likely to be affected by motorized watercraft. A ratio less than 0.10 is considered low, while a ratio greater than 0.50 is considered high.

Most environmental problems associated with boating activity occur in shallow water, thus a maximum of $30 \mathrm{~m}$ is a shoreline safety environmental protection zone.

Optimal number of boats $=\frac{\text { usable lake area }}{\text { Optimum boating density }}$

Usable lake area $=$ adjusted lake area (subtracting a $30 \mathrm{~m}$ shoreline safety environmental protection zone)

Optimum boating density $=10-50$ acres/boat.

\subsection{Percentage at peak use}

Carrying capacity $=\frac{\text { Estimated No.of boats at peak use }}{\text { Optimal No.of boats }}$

Carrying capacity is exceeded when the percentage at peak use is greater than $100 \%$. Determination of the minimum space required for boat use is a universally accepted standard for different type of boat use as shown in Table 2 .

\section{Results and Discussion}

As part of the study, an evaluation of the physical characteristics of each of the four study lakes was conducted (Table 3).

Table 3. Physical characteristics of the Study Area

\begin{tabular}{||c|c||}
\hline \multicolumn{2}{|c||}{ Vembanad Lake Characteristics } \\
\hline Lake Surface Area & $77.14 \mathrm{sq} . \mathrm{km}$ \\
\hline Maximum Depth & $8 \mathrm{~m}$ \\
\hline Mean Depth & $6.5 \mathrm{~m}$ \\
\hline Shoreline Length & $46.32 \mathrm{~km}$ \\
\hline Shoreline Development Factor & 1.34 \\
\hline
\end{tabular}

House boats for tourism purposes in Vembanad lake have greater than $100 \mathrm{HP}$ engines and are of huge size. In addition, the area is ecologically fragile with rich biodiversity; the minimum area/average area for each engine boat can be roundup as 50 acres/boat for carrying capacity assessment. The lake area under study was $77.14 \mathrm{sq}$. km. The length of the study area is $17.19 \mathrm{~km}$. and breadth is $6.82 \mathrm{~km}$. The shore line length is calculated as $46.32 \mathrm{~km}$. The usable lake area is $64.82 \mathrm{sq}$. $\mathrm{km}$. The shore line safety environmental protection zone is $12.32 \mathrm{sq}$. $\mathrm{km}$. The optimal boat density is assumed 50 acres/boat. Thus, the optimal number of boats in the lake is by dividing the usable lake area by the optimum boat density. The result is 130 which means only 130 boats are allowable in the study area at a time. But the number of boats observed at the peak time is 167 , so the percentage of the peak use carrying capacity is calculated as $128.5 \%$. If the carrying capacity is exceeded when the percentage at peak use is greater than $100 \%$, the total number of boats in the study area is estimated to be 600; as a result Density range (acres/boat) that is its Physical Capacity Assessment is high (in the high density category). In the study area, the area of lake less than $5 \mathrm{ft}$. deep is nearly 12.32 hect. Depth of Vembanad lake varies from 2 metres to 8 metres. Average depth is $6.5 \mathrm{~m}$.

The shoreline developmental factor (SDF) is a measure of the degree of irregularity in the shape of the shoreline. A perfectly round lake would have a SDF of 1.0. The higher the SDF, the more convoluted the shoreline. Irregular shorelines imply greater safety risks as well as ecological consequences (Wagner 
1991). The SDF of the study area is 1.34 which has moderate irregularity in the shore line.

In a study which assessed the impact of motorized watercraft on lakes, Wagner (1991) has noted: The ratio of the length of the shoreline around the lake to the circumference of a circle with the same area as the lake [SDF] provides a size independent measure of lake shape and indicates much about how motorized watercraft could affect the water body. Higher ratios suggest irregular shorelines with more water front per unit area than smaller ratios. Numerous coves may serve to isolate impacts, but there is a greater potential for the shoreline to be affected. High ratios also imply greater safety risks as well as ecological consequences.

Shallowness Ratio (SR) is the ratio of the area of lake less than $5 \mathrm{ft}$. deep to the total area of lake. The SR represents the proportion of the lake bottom likely to be affected by motorized watercraft. A ratio less than 0.10 is considered low, while a ratio greater than 0.50 is considered high. The SR of the study area 0.16 indicates that the motorized water crafts have moderate impact on the lake bottom (Table $4 \& 5$ ) (Fig 1).

\begin{tabular}{|c|c|c|c|}
\hline Table 4. & & ement & riteria classification \\
\hline \multirow{2}{*}{ Use level } & \multicolumn{3}{|c|}{ Incidence of conflict } \\
\hline & High & Moderate & Low \\
\hline Very high & Class I & Class I & Class III \\
\hline High & Class I & Class I & \begin{tabular}{|l|l|} 
Class II & Class III \\
\end{tabular} \\
\hline Moderate & Class I & Class II & Class II \\
\hline Low & Class II & Class II & Class IV \\
\hline Very low & Class II & Class II & Class IV \\
\hline
\end{tabular}

Table 5. Different class levels and management options

\begin{tabular}{||l|l|l||}
\hline & \multicolumn{1}{|c|}{ Existing Boating condition } & \multicolumn{1}{|c|}{ Management options } \\
\hline Class I & $\begin{array}{l}\text { Moderate to very high boat traffic density at } \\
\text { peak use times and high to very incidence of } \\
\text { conflict }\end{array}$ & $\begin{array}{l}\text { No new development is recommended since it may } \\
\text { worsen the condition for safety and enjoyment. } \\
\text { Greater law enforcement, boating petrol and } \\
\text { educating the people. }\end{array}$ \\
\hline Class II & $\begin{array}{l}\text { Moderate to high boat traffic density at peak } \\
\text { use times and moderate to very low incidence } \\
\text { of conflict. }\end{array}$ & $\begin{array}{l}\text { Consideration of new development is possible in } \\
\text { combination with management and resource factors. }\end{array}$ \\
\hline Class III & $\begin{array}{l}\text { High to very high boat traffic density at peak } \\
\text { use times but low incidence of conflict. }\end{array}$ & $\begin{array}{l}\text { Development is possible up to the carrying capacity } \\
\text { level. Sustainable management options for resource } \\
\text { management. }\end{array}$ \\
\hline Class IV & $\begin{array}{l}\text { Low or very low boat traffic density, even at } \\
\text { peak use times, and low incidence of conflict. }\end{array}$ & $\begin{array}{l}\text { A new sustainable development plan to preserve and } \\
\text { protect the natural environment. }\end{array}$ \\
\hline
\end{tabular}

Around 2 lakhs of tourists from all over the world visit the Vembanad wetland every year. Several studies have been conducted to evaluate environmental impacts associated with boating (Bouchard 2000; Warrington 1999; Asplund and Cook 1997; Asplund 1996; Wagner 1991). Environmental impacts most commonly associated with boating activities include fuel emissions from boat motors, suspension of bottom sediments, decreased water transparency, shoreline erosion, destruction of fish spawning areas, and loss of valuable fish and wildlife habitat. Although fuel emissions from motor boats are often cited as major sources of pollution, recent technological advances have greatly reduced pollution inputs associated with outboard motor discharges.

In addition to fuel emissions, the other environmental impacts associated with boating activity will vary widely depending on a number of factors such as lake size, depth, and level of boat use. In general, the shallower portions of lakes (i.e., areas less than 5 feet deep) are most susceptible to adverse environmental impacts associated with motor boat activities (Wagner 1991). This is especially true with regard to sediment re-suspension, reduced water transparency, and impacts on fish and wildlife habitat. Wagner (1991) has observed that the shallowness ratio, which compares the area of the lake less than 5 feet deep to the total lake area, is indicative of the lake bottom area likely to be directly affected by motorized watercraft.

There is continuous mining of fossils of white limestone with a dredger of Travancore Cements Ltd., a public sector undertaker. White limestone is the main raw material used for cement making. These dredgers dredge the floor of the lake as a whole and white stone is separated and sand deposited in the lake itself. As a result the floor of the lake becomes dangerously uneven with lots of mounds and pits. Thannermukkom barrage constructed across Vembanad lake to increase paddy cultivation became a serious threat to the health of the lake as well as people residing around the lake.

Epidemics have become regular phenomena in the southern part of the barrage. The fisheries sector also faced a serious threat. The fish production in the entire wetland has been quantified to 7,200 tonnes per annum. In a study conducted by the Regional Agricultural Research Station (RARS), Kumarakom, the exploited catches on the southern part of the barrage has been found to be only 584 tonnes per annum, a mere $7 \%$ of the total, which obviously indicates the extent of damage to fish wealth (Padmakumar et al. 2001). 
A recent study of the effects of motor boats on aquatic plants has concluded that motor boat activity significantly affects plant biomass, primarily through scouring of the sediment substrate and direct cutting (Asplund and Cook 1997). Different types of weeds are alarmingly spreading in the lake. Among them Eichhornia crassipes is the most dangerous. About 20 dams (both irrigation and power generation) have been constructed in the upstream of the rivers draining in to the wetland. These dams restrict or minimize the water flow to a great extent, and thus flushing is affected which further has increased silting up. Large scale deforestation in the catchment area of the rivers has disrupted the balanced flow of the rain fed rivers and it has increased soil erosion in the high ranges. Other threats to the lake are industrial effluents, agrochemicals used for paddy cultivation including fertilizers, insecticides, etc., domestic sewage and urban wastes from cities. Latrines constructed along the banks of the lake, nearby canals and rivers open defecation into the water body, whereby coconut husk retting and associated operations result in release of polyphenols. Irrational construction of innumerable roads in and around the wetland blocks increases silt and weed growth.

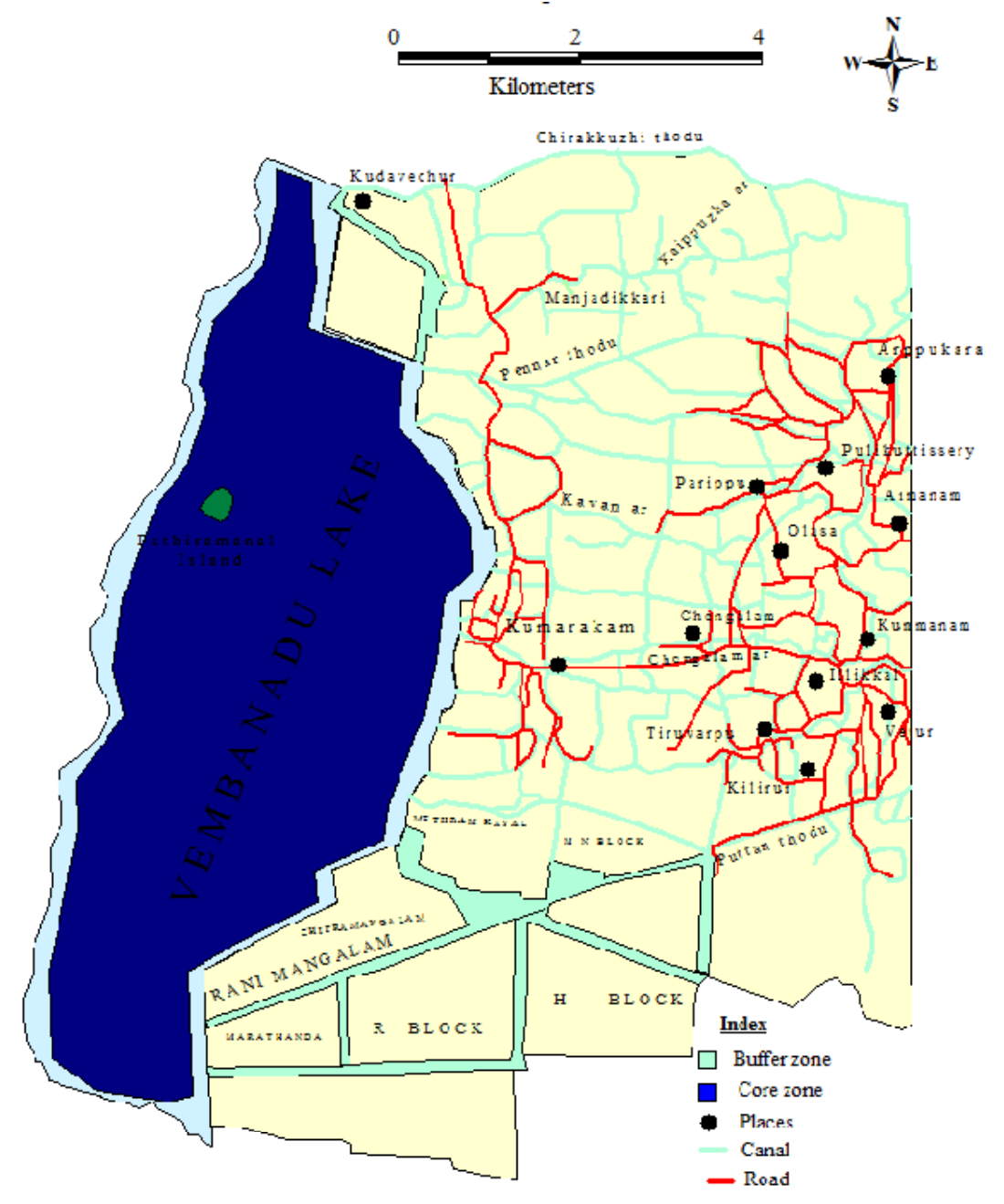

Fig. 1. Buffer zone map

\section{Conclusions}

Tourism is one of the world's fastest growing industries as well as the major source of foreign exchange earnings and employment for many developing countries, herewith it is increasingly focusing on the natural environment. Tourism as an industry provides a major part in the total GDP worldwide. The present tourism activities around Vembanad lake have many negative impacts. More than 600 house boats are plying the lake for tourists; the wastes including toilets and septic tanks are a serious issue. The microbial contamination of the lake during the period of the study has become much higher especially due to faecal contaminations, which prevent tourists from engaging in contact water sports. The physical boat carrying capacity of the lake is much above the sustainable level. Major problems are: solid wastes, liquid wastes, land reclamation, oil and grease pollution, unplanned construction and recreational activities in addition to the over exploitation of natural resources.

The ecosystem of Vembanad wetland being highly fragile comes under the Ramsar site for special protection and conservation. Mangrove swamps are the breeding place of many birds, clearing of the trees 
in this area and increased tourist activities affect the bird populations including migratory birds. A good number of mangroves and mangrove associates are present in the area. There are 17 species of mangroves coming under rare, very rare, very common, common and occasional categories. Tourism intensity contributes to the degradation of certain sensitive wetlands near tourist hotspots.

Recreation and tourism are listed as the second major use of the Ramsar site wetlands (Frazier 1999). There are more than 50 species of fishes present in the sanctuary, overexploitation, introduction of exotic species and pollution may lead to extinction of many natural varieties. Any massive change in such an ecosystem leads to social, economic and ecological imbalances. Hence, tourism activities in the Vembanad wetland should be sustainably based on carrying capacity of the ecosystem.

\section{References}

Asplund, T. R. and Cook, C. M., Effects of motor boats on submerged aquatic macrophytes. Journal of Lake and Reservoir Management, 1997, 13(1), 1-12.

Asplund, T. R., Impacts of motor boats on water quality in Wisconsin lakes. Monona, WI: Wisconsin Department of Natural Resources Bureau of Research. 1996.

Aukerman, R., Haas, G., Lovejoy, V., \& Welch, D., Water Recreation Opportunity Spectrum (WROS) user's guidebook. 2004. Retrieved August 7, 2005 from http://www.usbr.gov/pmts/planning/wros/wros_report.pdf

Bouchard, R., Power boating: Polluting our lakes? Lakeline, 2000, 20(4), 34-37.

ERM, Inc., Deep Creek Lake boating and commercial use carrying capacity study. Prepared for Maryland Department of Natural Resources. Proposal No. KOOR2200624. 2004, Retrieved June 10, 2005 from dnrweb.dnr.state.md.us/download/dclfinalreport.pdf

Garg, J. K., Singh, T. S and Murthy, T. V. R., Wetlands of India - Project Report. Space Applications Centre. Ahmadabad. 1998.

GOK (Government of Kerala), Tourist Statistics of Kerala. Department of Tourism, Govt of Kerala. 2002.

GOK (Government of Kerala), Tourist Statistics of Kerala. Department of Tourism, Govt of Kerala. 2006.

Islam, M. Z. and Rahmani A. R., Important Bird Areas in India: Priority sites for conservation. Indian Bird Conservation Network, Bombay Natural History Society and Birdlife International (UK). 2004, 1,200 pp.

Jaakson, R., Buszynski, M. D. and Botting, D., Carrying capacity and lake recreation planning. The Michigan Riparian, 1990, pp. 11-12, 14.
Jones, W. J., Balancing Recreational User Demands and Conflicts on Multiple Use Public Waters. American Fisheries Society Symposium, 1996, 16, 179-185.

Kokkranikal, J. and Morrison, A., Entrepreneurship and sustainable tourism: A case study of the houseboats of Kerala. Tourism and Hospitality Research, 2002, 4(1), 7-20.

Kusler, J. A., Carrying Capacity Controls for Recreation Water Uses. Upper Great Lakes Regional Commission. 1972.

Maltby, E. and Turner, R. E., Wetlands are not Wastelands. Geographical Magazine LV, 1983, 92-7.

MoEF. Wetlands of India - A directory. Ministry of Environment and Forests, Govt. of India, New Delhi. 1990.

Nameer, P.O. An overview of the wetlands of Kerala and their conservation: Birds of wetlands and grasslands. (Proceedings of the Salim Ali Centenary Seminar 1996). Bombay Natural History Society, Mumbai. 2002.

Neelakandan K. K., 'Keralathile Pakshikal' ("Birds of Kerala"). Kerala Sahitya Academy, Thrissur 2004. ISBN: 81-7690-067-2.

Padmakumar K.G., Krishnan, A., Radhika, R., Manu, P. S. and Shiny, C. K. Open water fishery interventions in Kuttanad, Kerala, with reference to fishery decline and ecosystem changes Riverine and Reservoir Fisheries, Challenges and strategies. Soc. Fish. Tech. (India), CIFT, Cochin. 2001, pp.15-24.

Progressive Architecture Engineering. Four Township recreational carrying capacity study: Pine Lake, Upper Crooked Lake, Gull Lake, Sherman Lake. 2001, http://www.kbs.msu.edu/ftwrc/publications/carryingcapacit y.pdf

Pushpangadan, K., Remittances, Consumption and Economic Growth in Kerala. Working Paper 343. Kerala, India: Centre for Development Studies. 2003.

Ramsar cites in Kerala Vembanad-Kol wetland www.kerenvis.nic.in/water/Ramsar\%20cites.pdf

Rao, N. and Suresh, K.T., Domestic tourism in India. In Ghimire, K.B. (Ed.). TCS (Tata Consultancy Services, 2000). Economic Benefits of Tourism Sector in Kerala. Report of the study conducted by TATA Consultancy Services, India. 2001.

Wagner, K. J. ,Assessing impacts of motorized watercraft on lakes: Issues and perceptions. In Proceedings of a National Conference on Enhancing the State's Lake Management Programs, 1991, 77-93.

Warren, R., \& Rea, P., Management of aquatic recreation resources. Columbus, $\mathrm{OH}$ : Publishing Horizons, Inc. 1989.

Warrington, P., Impacts of outboard motors on the aquatic environment. British Columbia Lake Stewardship Society 1999. (http://www.nalms.org/bclss/impactsoutboard.htm).

WTTC (World Travel and Tourism Council). The Travel and Tourism Satellite Account for Kerala: Impact of Travel and Tourism on the Jobs and the Economy. New Delhi: WTTC. 2002. 
Brilliant Rajan - Research Scholar at Centre for Remote Sensing and GIS, School of Environmental Science, Mahatma Gandhi University.

Main research areas: Carrying capacity, environmental management, sustainable development. Address: $\quad$ Kottayam, Kerala- 686560

Tel.: $\quad 9446917941$

E-mail: $\quad$ brilliantrajan@gmail.com
Vincy Mary Varghese - Research Scholar at Centre for Remote Sensing and GIS, School of Environmental Science, Mahatma Gandhi University. Main research areas: hydrological modelling, GIS, Remote sensing, environmental management, sustainable development.

Address: $\quad$ Kottayam, Kerala- 686560

E-mail: $\quad$ vincybrilliant@gmail.com

Dr. A. P. Pradeepkumar - Assoc. Professor at School of Environmental Science, Mahatma Gandhi University.

Main research areas: environmental disaster management, geology, petrology.

Address: $\quad$ Kottayam, Kerala- 686560

E-mail: $\quad$ geo.pradeep@gmail.com

\title{
Rekreacinè ežero ekosistemos talpa laisvalaikio valtimis. (Vembanado ežeras, Kerala, Pietų Indija)
}

\author{
B. Rajan, V. M. Varghese, A. P. Pradeepkumar \\ Aplinkos apsaugos moksly mokykla, Mahatmos Gandžio universitetas, Kottayam, Indija
}

(gauta 2011 m. balandžio mèn.; atiduota spaudai 2011 m. birželio mèn.)

Rekreacinę talpą apibrež̌ia valčių skaičius, kuris gali būti naudojamas nepažeidžiant saugios rekreacijos reikalavimų, estetinio vaizdo ir (arba) aplinkos kokybès. Ežerai turi ribotą rekreacinę talpą, todèl šiame straipsnyje analizuojama jų perkrova vandens plaukimo priemonèmis, vertinamos ežero rekreacinès talpos galimybès taikant Vembanado ežero pavyzdị. 